\title{
EDITORIAL
}

\section{Pharmacy workforce education challenges and responses to the COVID-19 pandemic in South Africa}

\author{
Mariet J Eksteen \\ Pharmaceutical Society of South Africa, South Africa
}

\section{Correspondence}

Mariet J Eksteen

Pharmaceutical Society of South Africa

435 Flinders Lane

Lynnwood

0081

South Africa

mariet@pssa.org.za

\begin{abstract}
The COVID-19 pandemic arrived unannounced and every facet of humankind was forced to align. In South Africa, all aspects of pharmacy education were impacted. Higher education institutions had to adopt emergency remote teaching strategies and skills to ensure pharmacy students had remote access to learning content to ensure that the academic year could be salvaged. For pharmacist interns, the writing of the pre-registration exam was delayed for most of the year. Pharmacists were subjected to compulsory continuing professional development for the first time in 2020. Despite several challenges experienced during this year, COVID-19 will be remembered for the change it initiated and hopefully, a positive outcome for access to education in the country.
\end{abstract}

According to The World Bank's country classification by income level, South Africa is an upper-middle-income country with a population of 59.6 million (World Bank Data Team, 2019; Statistics South Africa [Stats SA], 2020). There are nine approved providers who currently offer the Bachelor of Pharmacy degree to more than 4000 pharmacy students spread over four undergraduate study years (South African Pharmacy Council [SAPC], 2020a; 2020b). Following graduation, a one-year internship must be completed in a pharmacy that is registered as an approved training facility under the direct personal supervision of a registered tutor, after which the candidate may register as a pharmacist (Department of Health [DoH], 2000a).

The South African government implemented a riskadjusted strategy to combat the pandemic by introducing alert levels as an indicator for the severity of the pandemic status in the country. A national lockdown commenced on 27 March and included drastic measures to contain the spread of the virus and save lives. During alert level five, only essential services were accessible to the public. In May, the alert level relaxed to level four during which extreme precautions to limit community transmission and outbreaks were still prioritised while allowing for some economic activity to resume. In June, regulations were further relaxed to alert level three, with continued restrictions on many activities but with the reopening of the economy where possible and the phasing-in of educational activities.

\section{COVID-19 impact on pharmacy education}

Prior to the announcement of the national lockdown, higher education institutions suspended academic 
activities for the autumn recess two weeks earlier than initially scheduled. During alert levels five and four, all learning activities were restricted to virtual or online teaching, as no face-to-face gatherings were allowed. Some institutions adopted emergency remote teaching (ERT) as early as April and May by implementing a variety of asynchronised strategies which included voice-over presentations, short videos, self-directed learning material, tutorials, and virtual discussion forums. These were made available through the institutions' online learning management systems. The reference to ERT points specifically to being born out of necessity and should not be seen in the same light as online teaching and learning which is a deliberate and carefully planned mode of delivery (Council of Higher Education [CHE], 2020).

Academic staff at the schools of pharmacy were under pressure to adapt current curricula for ERT and virtual platforms. Not only does the development of online teaching material take longer, but staff must also engage with students individually via e-mail, chat rooms, and messages. Assessments also had to change and be adapted for online use. Regardless of the COVID-19 pandemic, South African schools of pharmacy have for several years had severe constraints in terms of academic capacity. An investigation in 2019 highlighted that some institutions had as many as nine academic staff vacancies out of 25 posts. In addition to the existing stressors, academic staff experienced challenges such as limited access to (sustainable) electricity, limited Internet connectivity, extended working hours, childminding, and household management which impacted staff well-being and performance.

With the publication of the directions for reopening institutions in June, a risk-adjusted strategy was implemented to phase-in the return to institutions for foundation training (Department of Higher Education and Training [DHET], 2020). The Minister of Higher Education and Training assured the country that no student or institution would be left behind in the attempt to save the academic year in higher education (Nzimande, 2020). The directive stated that a maximum of $33 \%$ of the learner population at an institution could return at the beginning of June (during level three), which was increased to $66 \%$ with the commencement of alert level two in mid-August. Once the country reaches alert level one, all learners will be allowed to return to training institutions. Criteria used to determine which students could return during level three included all medical students, senior and final-year students, and students without ideal living conditions for remote learning. This did not mean that all institutions opted to have students back on campus initially or since. Some institutions continue to offer online learning as far as possible and will only have students return for work-based learning or clinical practical sessions towards the end of the year.

As mentioned above, one of the key factors for consideration by institutions when planning their reopening were learners whose living conditions at home are of such a nature that they cannot participate meaningfully in remote teaching and learning. These conditions could be small living spaces that are sometimes occupied by several extended family members, an inability to study at home, absence of electricity, poor Internet connectivity, lacking affordability of Internet access, and lacking availability of suitable devices such as laptops and tablets. Unfortunately, the inequities from the predemocratic era in South Africa and the current lack of investment in key functional areas have once again surfaced during the COVID-19 pandemic and highlighted that South Africa's education system has not yet been transformed to redress the mistakes of the past. Some institutions assisted with sourcing devices for students to purchase at preferential rates, whereas other institutions obtained external sponsorships to cover the cost of devices and data. Regardless of these attempts, there were still scenarios where above-mentioned circumstances could not be remediated, and institutions had to provide learning material in hard copy and distribute these to students. Another unique challenge faced during COVID-19 are the students from neighbouring countries who study pharmacy in South Africa. The majority, if not all, returned home prior to the lockdown and have not been able to return due to the closure of international borders. Institutions constantly liaise with these students to offer support and information.

Intense pressure was placed on institutions to ensure that their infrastructure and facilities met the requirements for the return of staff and learners, including adhering to the requirements of the various occupational health and safety directives and guidelines for the management of, and response to, the COVID-19 outbreak. Institutions had to ensure isolation facilities, sanitation, screening of individuals upon entering an institution, and provision of personal protective equipment (PPE).

Although the second semester of the final year commenced later than the initial academic calendar this year, it consisted mostly of practical work or externships at work-based learning sites in practice settings (SAPC, 2017). This was greatly impacted by the pandemic as healthcare facilities did not allow non-essential individuals into their facilities, not only to avoid a possible spread of 
the virus, but also due to limited capacity to tutor these students. Hence, these activities were in some instances diverted to community pharmacies. Alternatively, video recordings and case studies were used to simulate hospital pharmacy experiences. Where pharmacy students could conduct work-based learning in hospital facilities, group size was reduced, and activities were restricted to non-COVID-19 areas as approved by the respective pharmacist at the facility. In the case of year-one to -three students, outstanding externship, clinical work-based learning, and all other laboratoryrelated practical work needed to be accomplished later in 2020.

Traditional sit-down examinations also needed adaptation to facilitate remote access. A mixture of multiple-choice question tests, take-home tests, and assignments were used to conduct formative assessments. At some institutions, it was decided to adapt non-essential modules for continuous assessment, while other essential or core modules had a final assessment during the institutions' adapted examination period.

Within the nine schools of pharmacy and in collaboration with the SAPC, every attempt was made to ensure proper quality assurance for the adjusted academic year and that final-year pharmacy students will complete their studies to commence with pharmacy internships in January 2021.

\section{COVID-19 impact on pharmacy internships}

During their internship, pharmacist interns must successfully complete the pre-registration evaluation which comprises the online submission of a continuing professional development (CPD) portfolio, the writing of the pre-registration examination and the submission of quarterly progress reports (SAPC, 2020c). Successful completion will allow the intern to register as a pharmacist for the purpose of performing pharmaceutical community service, a compulsory one-year remunerated provision of services in a public health facility ( $\mathrm{DoH}$, 2000b). Both the CPD portfolio and progress reports are mostly within the interns' control, and they would be able to manage the completion thereof. Traditionally, the pre-registration examinations are hosted in March, July, and October annually by the SAPC. The largest cohort of interns register for the exam in July, as interns have to complete six months of internship before they can attempt the exam (SAPC, 2020d). Under normal circumstances, these online examinations are conducted simultaneously at various centres in all provinces across the country. Prior to the exam scheduled for July, an examination workshop was hosted by the SAPC in all provinces to familiarise interns with the exam format and other information.

During the pandemic, SAPC had to offer the examination workshop virtually and upload recordings thereof to their website. The July and October examination dates had to be pushed back as time went by in anticipation of relaxed lockdown regulations and the expectation that group events might be permitted again. In the absence of the latter, the council had no other choice but to reschedule these exams for October and November, respectively, as the successful completion of the internship is crucial for a sustained supply of workforce in the profession in the coming year. The same open-book exam format will be followed, and interns may use approved references during the exam but they may not access electronic references or receive help from others. The impact of the pandemic on the pre-registration examination for pharmacist interns in South Africa was not limited to the rescheduling of exams. The council had to incorporate additional security measures, as interns will now take the exam from individual locations and not under the supervision of an invigilator.

\section{COVID-19 impact on CPD for pharmacists}

The Minister of Health published the regulations regarding CPD for pharmacists in May 2019 (DoH, 2019). From 2020, it is compulsory for pharmacists to comply with CPD requirements. It is unfortunate that after so many years of anticipating the publication of CPD regulations, it happened in a year where the world has to manage a pandemic. What was an initially slow adoption of CPD compliance and participation, due to the impact of COVID-19 on pharmacists as frontline workers, is now gaining momentum with the country's easing of lockdown restrictions, a national decrease in daily COVID-19 infections, an increased adoption of virtual presence, and a variety of online events to choose from. Since the declaration of the pandemic, several stakeholders hosted virtual webinars and symposiums which allowed access to learning content and material. Not only is this approach preferred during the pandemic where social distancing is compulsory, but several unintended benefits were also discovered. Pharmacists living in rural areas are now able to gain access to content without travelling long distances to metropolitan cities to attend face-to-face evening events. This further opened an opportunity for bringing international experts to a South African audience. 


\section{Conclusion}

The COVID-19 pandemic has significantly transformed the provision of, and access to, education with endless possibilities to ensure workforce transformation. As a country, South Africa will have to ensure prioritisation of the existing inequalities in access to education still visible 26 years into democracy so that no one is left behind, as there is no going back to the way things were before the pandemic.

\section{References}

CHE [Council of Higher Education]. (2020). Quality assurance guidelines for emergency remote teaching and learning and assessment during the COVID-19 pandemic in 2020. Available at: https://firebasestorage.googleapis.com/v0/b/che2020-c5efd.apps pot.com/o/website\%2Fq0q2svsligf1.pdf?alt=media\&token=a9091 867-a851-4bc5-a26d-50e95cfffa84

DoH [Department of Health]. (2000a). Pharmacy Act, 1974 (Act no 53 of 1974): Regulations relating to pharmacy education and training (notice 1156). Government Gazette, 21754, 4. Available at: http://www.kznhealth.gov.za/interns2.pdf

DoH [Department of Health]. (2000b). Pharmacy Act, 1974 (Act no 53 of 1974): Regulations relating to the performance of pharmaceutical community service (notice 1157). Available at: https://pharmcouncil.co.za/media/default/documents/Communit y Service\%20(2000).pdf

DoH [Department of Health]. (2019). Pharmacy Act, 1974 (Act no 53 of 1974): Regulations relating to Continuing Professional Development (notice 668). Government Gazette, 42464, 125. Available at: https://www.sapc.za.org/Media/Default/ Documents/CPD\%20regulations\%20-\%20English\%20(003).pdf

DHET [Department of Higher Education and Training]. (2020). Disaster Management Act, 2002 (Act 57 of 2002): Directions for reopening of institutions offering qualifications registered on the Occupational Qualifications Sub-Framework. Government Gazette, 43486, 9. Available at: https://juta.co.za/documents/950/43486 29-6 HighEduTrain.pdf

Nzimande, B. (2020). Minister of Higher Education, Science and Innovation statement on progress in the implementation of measures by the Post School Education Sector in response to Covid-19 epidemic. Available at: https://www.gov.za/speeches/ minister-blade-nzimande-progress-implementation-coronavirus-c ovid-19-measures-post-school

Stats SA [Statistics South Africa]. (2020). 2020 Mid-year population estimates. Available at: http://www.statssa.gov.za/?p=13453

SAPC [South African Pharmacy Council]. (2017). Pharmacy Act, 1974 (Act no 53 of 1974): Good Pharmacy Education Standards (Higher Education and Training). Government Gazette, 41256, 183 Available at: https://www.pharmcouncil.co.za/media/default/ documents/Good Pharmacy Education Standards (HET) (2017). pdf

SAPC [South African Pharmacy Council]. (2020a). Updated list: approved providers and courses. Available at: https://www. sapc.za.org/Media/Default/Documents/Updated\%20list\%20of\%2 Oproviders\%20-\%20November\%202020.pdf
SAPC [South African Pharmacy Council]. (2020b). Students By University. Available at: https://interns.pharma.mm3.co. za/Statistics/StudentsByUniversity?class=btn\%20btn-primary

SAPC [South African Pharmacy Council]. (2020c). Intern and tutor manual for the pre-registration experience of pharmacist interns. Available at: https://www.sapc.za.org/Media/Default/ Documents/2020\%20Intern\%20and\%20Tutor\%20Manual Final v $\underline{2 . p d f}$

SAPC [South African Pharmacy Council]. (2020d). Pharmacist Intern. Pre-registration examination. Available at: https://www. pharmcouncil.co.za/Intern pre registration

World Bank Data Team. (2019). New country classifications by income level: 2019-2020. Available at: https://blogs.world bank.org/opendata/new-country-classifications-income-level-201 $\underline{9-2020}$ 